\title{
Identifikasi Kandungan Senyawa Fitokimia Pada Daun dan Akar Lamun di Pantai Samuh Bali
}

\author{
Ni Luh Gede Widya Bintang Gustavina ${ }^{* *}$, I Gusti Bagus Sila Dharma a, Elok Faiqoh a \\ aProgram Studi Ilmu Kelautan, Fakultas Kelautan dan Perikanan, Universitas Udayana, Kampus UNUD Bukit Jimbaran, Bali 80361, Indonesia \\ *Penulis koresponden. Tel.: +62-85-737-304-192 \\ Alamat e-mail: bintanggustavina@yahoo.com
}

Diterima (received) 16 Juli 2017; disetujui (accepted) 5 November 2017; tersedia secara online (available online) 7 November 2017

\begin{abstract}
Seagrass is the only flowering plant which has a true roots, leaves, and stems, an angiosperm plant that adapted to live entirely in the ocean. Seagrass produces several compounds which produced through secondary metabolism, one of the secondary metabolism is the phytochemicals. Seagrass ecosystem in Tanjung Benoa was discovered along Samuh Beach, where 9 kinds of seagrass species were found around the seagrass ecosystem in Tanjung Benoa. Samuh Beach has a tranquil water conditions and sandy substrate. The activities of marine tourism and hotel waste disposal in Tanjung Benoa waters cause major ecological pressure and physical pressure for the seagrass ecosystem. This study aims to determine the content of phytochemicals in the leaves and roots of seagrass. Screening method was used to determine the content of bioactive alkaloids, flavonoids, saponins, steroids, and tannin compounds. Each of these compounds has an important role in the seagrass. The existence of chemical compounds of the flavonoid, alkaloid and steroid groups in the roots and leaves of Cymodocea rotundata seagrass, Enhalus acoroides, Thalassia hemprichi, Halophila ovalis, Halophila minor, Halodule uninervis and Sryngodium isoetifolium in this study indicate that the seven species of seagrass has potential as a natural chemical antifouling, antifungal, and antibacterial.Then the seagrass will be protected from the danger of predators or epiphanies that interfere with the growth of seagrass and the ecosystems on Samuh Beach will remain intact.
\end{abstract}

Keywords: phytochemical;pressure; seagrass;Samuh Beach

\begin{abstract}
Abstrak
Lamun merupakan satu satunya tumbuhan angiospermae atau tumbuhan berbunga yang memiliki daun, batang, dan akar sejati yang telah beradaptasi untuk hidup sepenuhnya di dalam laut. Lamun menghasilkan beberapa senyawa yang dihasilkan melalui metabolisme sekunder, salah satunya adalah fitokimia. Ekosistem padang lamun di Tanjung Benoa ditemukan di sepanjang Pantai Samuh, dimana terdapat 9 spesies lamun yang ditemukan di kawasan tersebut. Pantai Samuh memiliki kondisi perairan yang tenang dan substrat berpasir.Aktivitas aktivitas wisata laut dan pembuangan limbah hotel di perairan Tanjung Benoa memberikan tekanan ekologis dan tekanan fisik yang besar bagi ekosistem lamun.Senyawa tesebut dapat ditemukan hampir di seluruh bagian lamun diantaranya daun dan akar.Penelitian ini bertujuan untuk mengetahui kandungan fitokimia pada daun dan akar lamun.Metode skrining digunakan untuk mengetahui kandungan senyawa bioaktif alkaloid, flavonoid, saponin, steroid dan tanin. Masingmasing senyawa tersebut memiliki peranan penting di dalam tubuh lamun. Keberadaan senyawa kimia golongan flavonoid, alkaloid dan steroid dalam akar dan daun lamun Cymodocea rotundata, Enhalus acoroides, Thalassia hemprichii,Halophila ovalis, Halophila minor, Halodule uninervis dan Sryngodium isoetifoliumpada penelitian ini menunjukkan bahwa ketujuh jenis lamun tersebut memiliki potensi sebagai bahan kimia alami antifouling, antibakteri,danantijamur. Adanya kandungan senyawa fitokimia pada lamun di daerah Pantai Samuh maka lamun yang berada di daerah tersebut akan terhindar dari ancaman bahaya predator atau epifauna yang menggangu pertumbuhan lamun dan ekosistem di Pantai Samuh akan tetap terjaga.
\end{abstract}

Kata Kunci:lamun; Pantai Samuh;tekanan; senyawa fitokimia 


\section{Pendahuluan}

Lamun merupakan salah satu tumbuhan air yang banyak ditemukan di perairan Indonesia memiliki biji tertutup(angiospermae) atau tumbuhan berbunga yang memiliki daun, batang, dan akar sejati yang telah beradaptasi untuk hidup sepenuhnya di dalam laut (Tuwo, 2011). Di seluruh dunia ditemukan 52 spesies lamun (Cobaco et al, 2009) dan 13 spesies diantaranya ditemukan di perairan Indonesia.Di Bali lamun banyak tersebar di perairan utara dan selatan, di daerah selatan Bali lamun ditemukan di sekitar perairan Tanjung Benoa (Faiqoh, 2015).Salah satu pantai yang memiliki lamun di perairan Tanjung Benoa yaitu Pantai Samuh.

Pantai Samuh terletak di sebelah selatan Tanjung Benoa yang memiliki panorama terumbu karang yang indah serta kondisi perairan yang tenang dan substrat berpasir.Pantai ini sangat mudah diakses para wisatawan lokal maupun mancanegara yang ingin berwisata.Di pantai Samuh ditemukan 9 jenis lamun yaitu Cymodocea serrulata,Enhalus acoroides, Halodule pinifolia, Halodule uninervis, Halophila ovalis, Halophila minor, Syringodium isoetifolium, Thalassia hemprichii, dan Thalassodendron ciliatum (Faiqoh, 2015). Daerah penyebaran lamun tersebut juga merupakan daerah tujuan wisata dan daerah budidaya rumput laut, sebagai daerah wisata dan budidaya, banyak aktivitas manusia yang terjadi, seperti lalu lintas perahu wisata yang padat, pembangunan daerah pesisir, kegiatan keagamaan (melasti), pengerukan sedimen, tempat mandi wisatawan, wisata air (diving, snorkling, banana boat, jet ski, surfing) serta pembuangan limbah dan pembangunan hotel. Banyaknya aktivitas - aktivitas wisata laut dan pembuangan limbah hotel yang terjadi di perairan Tanjung Benoa memberikan dampak yang buruk bagi perkembangan ekosistem lamun di pantai tersebut.

Tekanan yang terjadi pada ekosistem lamun tidak hanya berlangsung selama satu hingga dua tahun melainkan tekanan tersebut akan terjadi selama bertahun-tahun, hal tersebut akan menjadi fakor pemicu bagi tumbuhan lamun untuk melakukanadaptasi dengan menghasilkan zat atau senyawa tertentu dengan tujuan menjaga ketahanan tubuhnya yaitu metabolit sekunder (Subhashini et al., 2013). Proses pembentukan senyawa metabolit sekunder dapat terjadi di dalam semua jaringan atau sel pada tumbuhan yang dipengaruhi oleh tingkat perbedaan dan perkembangannya.

Senyawa metabolit sekunder ini bisa ditemukan pada suatu organ atau jaringan yang terpapar oleh stres dari lingkungan seperti infeksi atau serangan pathogen salah satunya pada daun dan akar lamun.Dalam penelitian ini bagian lamun yang digunakan adalah daun dan akarnya. Daun berfungsi sebagai tempat berlangsungnya proses fotosintesis sedangkan akar untuk menyimpan zat hara, menyokong tumbuhan dan menyimpan air (Haryanti, 2010).Salah satu bagian dari senyawa metabolit sekunder yaitu fitokimia dimana fitokimia merupakan senyawa bioaktif yang dihasilkan oleh tumbuhan salah satunya tumbuhan lamun (Rohmatussholihat, 2009). Keberadaan senyawa fitokimia pada tumbuhan khususnya lamun banyak digunakan untuk obatobatan yang bermanfaat bagi manusia.

Beberapa penelitian mengenai fitokimia pada lamun telahbanyak dilakukan misalnyaolehTeffo et al.,(2009) di Sulawesi Utara, Mardiyana et al.,(2014) di Pulau Pramuka,Mani et al., (2012) di IndiadanSudirman et al., (2016).Namun di daerah Bali penelitian tentang fitokimia belum pernah dilakukan serta perbandingan fitokimia pada daun dan akar lamun juga belum pernah dilakukan, melihat dari fungsi dari fitokimia yang banyak digunakan untuk pembuatan obat- obatan maka penelitian ini perlu dilakukan.

\section{Metode Penelitian}

\subsection{Waktu dan Tempat Penelitian}

Penelitian ini dilakukan selama 3 bulan, mulai dari bulan November 2016 sampai Januari 2017.Lokasi pengambilan sampel lamun dilakukan di Pantai Samuh, Bali dan untuk uji kandungan senyawa fitokimia dilakukan di laboratorium Fakultas Kelautan dan Perikanan Universitas Brawijaya Malang. Lokasi pengambilan sampel akar dan daun lamun dapat dilihat pada gambar 1 .

\subsection{Alat dan Bahan}

Alat dan bahan yang digunakan dalam penelitian ini yaitu: tabung reaksi, gelas piala pipet tetes, timbangan analitik, lamun, pereaksi jenis Mayer, Weagner, Dragendroft, $\mathrm{H}_{2} \mathrm{SO}_{4}$, Cloroform, Anhidrida asetat, bubuk Magnesium, Alkohol, Amil alcohol, asam sulfat, Aquades, $\mathrm{HCl} 2 \mathrm{~N}$, dan $\mathrm{FeCl}$. 


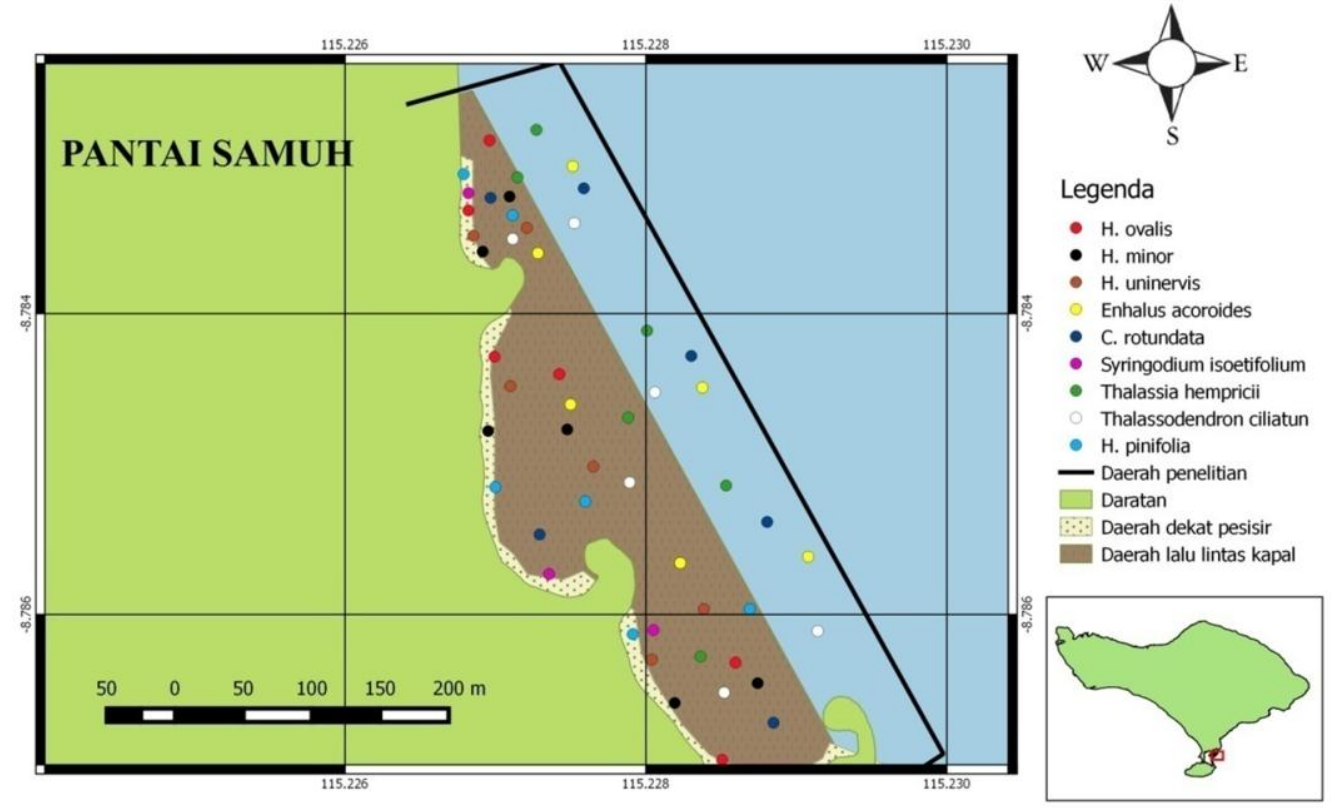

Gambar 1. Peta Lokasi Pengambilan Sampel

\subsubsection{Prosedur Pengambilan Sampel}

Proses pengambilan sampel semua jenis lamun dilakukan dengan metode random sampling di Pantai Samuh. Sampel lamun diambil langsung dari habitatnya menggunakan alat yang bernama sekop digabungkan sesuai dengan jenis yang didapat, kemudian sampel dibawa menggunakan plastik ke Laboratorium Fakultas Kelautan dan Perikanan Universitas Udayana untuk dicuci guna menghilangkan epifitnya, selanjutnya dipisahkan antara bagian daun dan akarnya. Selanjutnya lamun dikering anginkan selama 2 minggu hingga lamun menjadi kering sesuai dengan penelitian yang telah dilakukan oleh (Atmoko dan Ma'ruf 2009).

\subsubsection{Uji Fitokimia}

Uji senyawa fitokimia untuk mengetahui jenis senyawa yang terdapat pada lamun dilakukan menggunakan metode skrining (Dewi et al., 2012). Sebagai berikut:

\section{Alkaloid}

Sebanyak 0,05 gram ekstrak kasar daun dan akar lamun dilarutkan ke dalam 20 tetes asam sulfat $2 \mathrm{~N}$, kemudian diuji menggunakan tiga pereaksi alkaloid, yaitu: meyer, weagner dan dragendroft. Uji ini positif jika terbentuk warna putih pada larutan yang ditambahkan pereaksi meyer, endapan coklat pada pereaksi dragendroft, dan endapan putih hingga jingga pada pereaksi weagner.

\section{Flavonoid}

Sebanyak 0,05 gram ekstrak kasar daun dan akar lamun ditambahkan dengan bubuk Magnesium(Mg), kemudian ditambahkan larutan amil alkohol sebanyak $0,4 \mathrm{ml}$, selanjutnya ditambahkan alkohol sebanyak $4 \mathrm{ml}$ dan dihomogenkan.Uji flavonoid dikatakan positif jika larutan membentuk lapisan amil alkohol dengan warna merah, kuning, atau jingga.

\section{Steroid}

Sebanyak 0,05 gram ekstrak kasar daun dan akar lamun dilarutkan ke dalam $2 \mathrm{ml}$ larutan kloroform, kemudian ditambahkan 10 tetes anhidrida asetat dan 3 tetes asam sulfat.Uji ini dikatakan positif jika larutan yang dihasilkan membentuk warna merah diawal kemudian berubah menjadi biru atau hijau diakhir pengujian.

4. Saponin

Sebanyak 0,05 gram ekstrak kasar daun dan akar lamun dilarutkan dengan aquades kemudian dipanaskan, jika muncul busa dan bertahan hingga 30 menit maka uji akan dilanjutkan dengan menambahkan 1 tetes $\mathrm{HCl} 2 \mathrm{~N}$, jika larutan mampu mempertahankan busa maka dikatakan positif.

\section{Tanin}

Sebanyak 0,05 gram ekstrak kasar daun dan akar lamun ditambah pereaksi $\mathrm{FeCl}_{3}$, adanya warna 
hijau kehitaman menunjukkan bahwa suatu bahan positif mengandung tanin.

\section{Hasil}

Berdasarkan penelitian yang telah dilakukan didapatkan hasil uji jenis kandungan senyawa fitokimia pada daun dan akar lamun yang disajikan dalam bentuk Tabel 1 .

1. Alkaloid

Dalam penelitian ini didapatkan bahwa jenis senyawa alkaloid ditemukan pada daun lamun Halophila ovalis dan Halophila minor, sedangkan pada daun jenis Cymodocea rotundata, Enhalus acoroides, Halodule pinifolia, Sryngodium isoetifolium, Thalasia hemprichii, dan Thalasodendron ciliatum tidak ditemukan senyawa alkaloid. Pada bagian akar lamun senyawa alkaloid hanya ditemukan pada jenis Halodule uninervis dan pada jenis Cymodocea rotundata, Enhalus acoroides, Halophila ovalis, Halodule pinifolia, Halophila minor, Sryngodium isoetifolium, Thalasia hemprichii, Thalasodendron ciliatum tidak ditemukan.

\section{Flavonoid}

Hasil dari penelitian ini, kandungan senyawa flavonoid ditemukan pada akar lamun jenis Enhalus acoroides, Halophila ovalis, dan Sryngodium isoetifolium.Jenis senyawa flavonoid ini tidak ditemukan akar lamun jenis Cymodocea rotundatta, Halophila uninervis, Halophila minor, Thallasia hemprichii dan Thalasodendron cilliatum.Hasil pengujian pada daun lamun kandungan senyawa flavonoid ditemukan pada daun jenis Enhalus acoroides, Halophila ovalis, dan Sryngodium isoetifolium.Senyawa flavonoid tidak ditemukan pada daun lamun jenis Cymodocea rotundata, Halodule uninervis, Halodule pinifolia, Halophila minor, Thalasia hemprichii dan Thalasodendron cilliatum.

\section{Steroid}

Dari penelitian ini didapatkan bahwa senyawa steroid ditemukan pada akar lamun jenis Halodule uninervis, Enhalus acoroides, Sryngodium isoetifolium, Thalasia hemprichii dan Thalasodendron ciliatum. Pada akar lamun jenis Halophila ovalis, Halophila minor, Cymodocea rotundata dan Halodule uninervis tidak ditemukan senyawa tersebut. Daun lamun jenis Cymodocea rotundata, Halodule uninervis, Halophila ovalis, dan Halophila minor positif mengandung senyawa steroid, dan untuk daun lamun jenis Enhalus acoroides, Halodule pinifolia, Sryngodium isoetifolium, Thalasia hemprichii, dan Thalasodendron ciliatum tidak mengandung senyawa jenis steroid.

\section{Saponin}

Dari hasil uji fitokimia yang membentuk busa ketika dikocokkan sehingga positif mengandung senyawa saponin yaitu pada akar lamun jenis Halodule uninervis, Enhalus acoroides dan Sryngodium isoetifolium.Sedangkan pada akar lamun jenis Cymodocea rotundata, Halophila ovalis, Halophila minor, Thalasia hemprichii, dan Thalasodendron ciliatum tidak ditemukan.Pada daun jenis Halodule uninervis, Thalasia hemprichii dan Sryngodium isoetifolium dikatakan positif mengandung senyawa saponin.Namun kandungan senyawa ini tidak ditemukan pada daun Cymodocea rotundata, Enhalus acoroides, Halophila ovalis, Halodule pinifolia, Halophila minor dan Thalasodendron ciliatum.

\section{Tanin}

Dari hasil pengujian yang telah dilakukan senyawa tanin ditemukan pada akar lamun jenis Halophila ovalis, Halophila minor, Enhalus acoroides, Halodule uninervis, Thalasia hemprichii dan Thalasodendronciliatum. Pada akar lamun jenis

\section{Tabel 1}

Hasil Uji Kandungan Senyawa Fitokimia Pada Daun Dan Akar Lamun

\begin{tabular}{cccccc|ccccc}
\hline \multirow{2}{*}{ Jenis lamun } & \multicolumn{9}{c}{ Daun } & \multicolumn{4}{c}{ Akar } \\
\cline { 2 - 10 } & Alkaloid & Flavonoid & Saponin & Steroid & Tanin & Alkaloid & Flavonoid & Saponin & Steroid & Tanin \\
\hline Cymodocea rotundatta & - & - & - & + & - & + & - & - & - \\
Enhalus acoroides & - & + & - & - & - & - & + & + & + & + \\
Halodule uninervis & - & - & + & + & - & + & - & + & + & + \\
Halophila ovalis & + & + & - & + & - & - & + & - & - & + \\
Halodule pinifolia & - & - & - & - & + & - & - & - & - & + \\
Halophila minor & + & - & - & + & - & - & - & - & - & + \\
Sryngodium isoetifolium & - & + & + & - & - & - & + & + & + & - \\
Thalassia hemprichii & - & - & + & - & - & - & - & - & + & + \\
Thalasodendron ciliatum & - & - & - & - & + & - & - & - & + & + \\
\hline
\end{tabular}


Halophila ovalis, Halophila minor, Cymodocea rotundata dan Sryngodium isoetifolium tidak ditemukan senyawa tersebut. Namun pada daun lamun Cymodocea rotundata, Halodule pinifolia, dan Thalasodendron ciliatum positif mengandung senyawa tanin, sedangkan pada daun Enhalus acoroides,Halodule uninervis, Halophila ovalis, Halophila minor, Sryngodium isoetifolium, dan Thalasia hemprichii hasil pengujian menunjukkan negatif.

\section{Pembahasan}

Tumbuhan merupakan sumber utama metabolit sekunder, namun beberapa organisme lain dilaporkan juga menghasilkan metabolit sekunder seperti bakteri, jamur dan hewan Nurjanah et al., (2012). Distribusi sumber metabolisme sekunder yang berasal dari tanaman juga berbeda-beda, semakin tinggi tingkatan taksonomi tanaman maka semakin banyak metabolit sekunder yang dihasilkan.

Metabolit sekunder yang umumnya diproduksi oleh organisme berperan untuk pertahanan diri dari lingkungan maupun dari serangan organisme lain termasuk organisme penempel/epifit, dan mencegah adanya infeksi dari patogen Marhaeni et al.,(2010). Pada lamun, epifit awalnya mengacu bagi seluruh organisme autrofik (produsen primer) yang tinggal menetap di bawah air menempel pada rhizoma batang dan daun lamun (Mardiyana et al., 2014). Keberadaan senyawa metabolit sekunder yang diproduksi oleh tumbuhan ini salah satunya untuk mempertahankan dirinya dari kondisi lingkungan yang kurang menguntungkan seperti suhu, iklim dan penyakit tanaman (Mardiyana et al., 2014). Kandungan senyawa bioaktif pada tumbuhan lamun yaitu senyawa jenis alkaloid, flavonoid, dan steroid diketahui dapat digunakan sebagai antibakteri (Ravikumar et al., 2008).

Lamun pada umumnya memiliki kandungan senyawa aktif yang berbeda tergantung dari morfologi setiap jenis lamun dan kandungan senyawa aktif yang dimilikinya (Marhaeni et al., 2010).Berdasarkan penelitian yang telah dilakukan oleh Faiqoh (2015) di Pantai Samuh jenis lamun yang mendominasi adalah jenis Enhalus acoroides, Halodule uninervis dan Sryngodium isoetifolium.

Senyawa alkaloid ditemukan pada daun lamun jenis Halophila ovalis dan Halophila minor, sedangkan pada akar lamun ditemukan pada jenis Halodule uninervis. Lamun jenis Halophila ovalis, Halophila minor mempunyai bentuk daun kecil yang memiliki banyak urat dan akar lamun jenis Halodule uninervis memiliki jenis akar yang sama dengan lamun jenis Halophila ovalis dan Halophila minor. Selain dari bentuk morfologinya menurut Ravikumar et al., (2008) lamun jenis Halophila ovalis, Halophila minor dan Halodule uninerois mempunyai kandungan senyawa alkaloid, flavonoid, saponin, steroid, fenol dan tanin yang terdapat pada semua bagian lamun. Senyawa alkaloid bersifat toksik dan memiliki rasa yang sangat pahit dimana dengan adanya senyawa ini lamun tersebut bisa terhindar dari ancaman hewan herbivora dan melindungi tanaman dari serangan serangga (Raharjo, 2013).

Berdasarkan hasil penelitian senyawa flavonoid ditemukan pada daun dan akar lamun jenis Enhalus acoroides, Halophila ovalis, dan Sryngodium isoetifolium. Menurut (Ali et al., 2012) Enhalus acoroides mempunyai daun rimpang yang tebal, panjang dan lebar sehingga cenderung memiliki kandungan senyawa aktif yang bersifat sebagai antibakteri hal ini disebabkan karena adanya ancaman bahaya dari epifit yang melekat daun lamun. Pada lamun jenis Cymodocea rotundata senyawa flavonoid ditemukan pada bagian akar lamun tersebut. Fungsi akar pada lamun yaitu sebagai tempat menyimpan oksigen untuk proses fotosisntesis (Haryanti, 2010) lamun jenis Cymodocea rotundata memiliki akar bercabang yang tidak teratur pada setiap ruas dengan adanya senyawa flavonoid ini bisa membantu melindungi akar-akar lamun ini dari serangan bakteri.

Kandungan senyawa aktif flavonoid bisa ditemukan pada semua bagian lamun mulai dari daun hingga akar. Menurut Dhuha (2016) adanya kandungan senyawa flavonoid di di dalam lamun tersebut dapat digunakan sebagai antioksidan.Senyawa kimia golongan flavonoid juga dilaporkan berperan aktif sebagai antifouling (Nurjanah et al., 2015).

Senyawa steroid dikenal sebagai senyawa hormon. Salah satu golongan steroid merupakan hormon seksual yang diproduksi di kelenjar kelamin yang berfungsi mengendalikan pertumbuhan serta perkembangan organ seksual (Santoso et al., 2011). Penelitian yang telah dilakukan oleh Ismarani (2012) pada lamun Halodule uninervis yang menghasilkan bahwa pada akar lamun tersebut mengandung senyawa steroid yang mampu bersifat sebagai antibakteri. Dalam penelitian ini kandungan senyawa steroid ditemukan pada akar lamun jenis Enhalus acoroides, Halodule uninerois dan Sryngodium isoetifolium. Pada daun lamun jenis Cymodocea rotundata, Halodule uninerois, Halophila ovalis, dan Halophila minor positif mengandung senyawa steroid. Lamun jenis Cymodocea rotundata, Halodule uninervis, Enhalus acoroides, Thalasia hemprichii dan Sryngodium isoetifolium ditemukan di daerah dekat tempat kapal-kapal bersandar dimana 
pada bagian bawah kapal tersebut biasanya banyak ditumbuhi jamur atau bakteri, sehingga lamun yang berada dibawah kapal tersebut memerlukan senyawa untuk mempertahankan dirinya. Senyawa golongan steroid ini yang berpotensi sebagai antifungi dan antibakteri dengan mekanisme merusak membran sel bakteri, sehingga menghambat pertumbuhan bakteri pada lamun.

Senyawa saponin ditemukan pada daun dan akar lamun jenis Halodule uninervis, Enhalus acoroides dan Sryngodium isoetifolium, hal ini disebabkan karena bentuk morfologi pada jenis lamun Enhalus acoroides, Halodule uninervis dan Sryngodium isoetifolium memiliki kandungan senyawa saponin yang bersifat sebagai anti serangga (Ali et al., 2012). Pada daun jenis Thalasia hemprichii senyawa saponin ini juga ditemukan. Thalasia hemprichii merupakan lamun yangmemiliki bentuk daun yang panjang dan ujungnya bulat dimanasenyawa ini berfungsi sebagai zat pelindung anti serangga dimana lamun yang mengandung senyawa ini akan terhindar dari bahaya dan saponin juga bersifat sebagai racun ikan karena memiliki rasa pahit sama seperti senyawa alkaloid (Nujanah et al., 2015).

Dalam penelitian yang dilakukan senyawa tanin ditemukan pada daun jenis Halodule pinifolia dan Thalasodendron ciliatum. Senyawa tanin juga ditemukan pada akar lamun jenis Enhalus acoroides, Halophila ovalis, Halophila minor, Thalasia hemprichii dan Thalasodendron ciliatum.Senyawaini berada dalam jumlah besar di daun, batang, akar, maupun buah yang belum masak (Raharjo, 2013).Senyawa tanin juga berpotensi sebagai senyawa antioksidan, karena senyawa tanin tersusun dari senyawa polifenol yang memiliki aktivitas penangkap radikal bebas (Ismarani, 2012).

Keberadaan suatu bahan aktif atau senyawa aktf dipengaruhi oleh faktor lingkungan yaitu suhu, radiasi cahaya matahari, udara (oksigen, karbondioksida dan uap air) serta kelembaban Ismarani (2012). Kondisi lingkungan yang buruk berpengaruh terhadap produksi metabolit sekunder pada organisme. Pada kondisi yang buruk lamun akan mengeluarkan metabolit sekundernya untuk bertahan hidup. Kandungan senyawa metabolit sekunder tidak hanya dipengaruhi oleh lingkungan semata, namun mereka juga dipengaruhi oleh tingkat asosiasi padang lamun yang tinggi. Ancaman dari biota-biota laut yang hidup pada lamun, juga cenderung menghasilkan senyawa bioaktifnya sebagai bentuk perlindungan diri dari biota laut.

Keberadaan senyawa kimia golongan flavonoid, alkaloid dan steroid dalam akar dan daun lamun Cymodocea rotundata, Enhalus acoroides, Thalassia hemprichii,
Halophila ovalis, Halophila minor, Halodule uninervis dan Sryngodium isoetifolium pada penelitian ini menunjukkan bahwa ketujuh jenis lamun tersebut memiliki potensi sebagai bahan kimia alami antifouling, antibakteri,dan antifungi (Mossiet al., 2009).

\section{Simpulan}

Kandungan senyawa alkaloid ditemukan pada daun lamun lamun jenis Cymodocea rotundata, Halophila ovalis, dan Halophila minor, senyawa flavonoid ditemukan pada daun lamun jenis Enhalus acoroides, Halophila ovalis, dan Sryngodium isoetifolium, senyawa saponin ditemukan pada daun lamun jenis Halodule uninervis, Thalasia hemprichii, dan Sryngodium isoetifolium. Senyawa steroid ditemukan pada daun lamun jenis Cymodocea rotundata, Halodule uninervis, dan Sryngodium isoetifolium.Senyawa tanin ditemukan pada daun lamun jenis Halodule pinifolia danThalasodendron ciliatum.

Kandungan senyawa alkaloid ditemukan pada akar lamun jenis Cymodocea rotundata, Halodule uninervis. Sedangkan untuk senyawa saponin ditemukan pada akar lamun jenis Halodule uninervis, Enhalus acoroides dan Sryngodium isoetifolium.Senyawa steroid ditemukan pada Enhalus acoroides, Halodule uninervis, dan Sryngodium isoetifolium. Senyawa flavonoid ditemukan pada akar lamun jenis Enhalus acoroides, Halophila ovalis, dan Sryngodium isoetifolium. Senyawa tanin ditemukan pada akar lamun jenis Enhalus acoroides, Halophila ovalis, Halophila minor, Halophila minor, Thalasia hemprichii dan Thalasodendron ciliatum.

Adanya kandungan senyawa fitokimia pada lamun di daerah Pantai Samuh maka lamun yang berada di daerah tersebut akan terhindar dari ancaman bahaya predator atau epifauna yang menggangupertumbuhan lamun dan ekosistem di Pantai Samuh akan tetap terjaga.

\section{Ucapan terimakasih}

Pada kesempatan ini penulis mengucapkan terimakasih kepada teman - teman Fakultas Kelautan dan Perikanan dan pihak - pihak lain yang membantu dalam penelitian ini.

\section{Daftar Pustaka}

Ali, M. S., Ravikumar, S., \& Beula, J. M. (2012). Bioactivity of seagrass against the dengue fever 
mosquito Aedes aegypti larvae. Asian Pacific journal of tropical biomedicine, 2(7), 570-573.

Atmoko, T., \& Ma'ruf, A. (2009). Uji Toksisitas dan Skrining Fitokimia Ekstrak Tumbuhan Sumber Pakan Orangutan terhadap Larva Artemia salina L. Jurnal Penelitian dan Konservasi Alam, 6(1), 37-45.

Cabaço, S., Machás, R., \& Santos, R. (2009). Individual and population plasticity of the seagrass Zostera noltii along a vertical intertidal gradient. Estuarine, Coastal and Shelf Science, 82(2), 301-308.

Dewi, C. S., Soedharma, D., \& Kawaroe, M. (2012). Komponen Fitokimia Dan Toksisitas Senyawa Bioaktif Dari Lamun Enhalus acoroides dan Thalassia hemprichii Dari Pulau Pramuka, DKI Jakarta. Jurnal Teknologi Perikanan dan Kelautan, 3(2), 23-27.

Dhuha, S., Bodhi, W., \& Kojong, N. (2016). Aktivitas Antibakteri Ekstrak Etanol Daun Lamun (Sryngodium isoetifolium) Terhadap Bakteri Pseudomonas aerugionosa. PHARMACON: Jurnal Ilmiah Farmasi, 5(1), 231-237.

Faiqoh, E., (2015). Distribusi Spasial Dan Identifikasi Biodiversitas Lamun Di Perairan Tanjung Benoa. Dalam Prosiding Seminar Nasional Sains dan Teknologi (Senastek). Denpasar, Bali, Indonesia, 29-30 Oktober 2015 (pp. 3 -11).

Haryanti, S. (2010). Jumlah dan distribusi stomata pada daun beberapa spesies tanaman dikotil dan monokotil. Buletin Anatomi dan Fisiologi dh SELLULA, 18(2), 21-28.

Ismarani, I. (2012). Potensi Senyawa Tannin Dalam Menunjang Produksi Ramah Lingkungan. CEFARS: Jurnal Agribisnis dan Pengembangan Wilayah, 3(2), 46-55.

Mani, A. E., Aiyamperumal, V., \& Petterson, J. (2012). Phytochemical of the seagrass Syringodium isoetifolium and its antibacterial and insecticidal activities. European Journal of Biological Science, 4(3), 63-67.

Mardiyana, M., Effendi, H., \& Nurjanah, N. (2014). Hubungan Biomassa Epifit Dengan Aktivitas Antioksidan Lamun Di Perairan Pulau Pramuka, Kepulauan Seribu, Dki Jakarta. Jurnal Pengolahan Hasil Perikanan Indonesia, 17(1), 7-13.

Marhaeni, B., Radjasa, O. K., Bengen, D. G., \& Kaswadji, R. F. (2011). Screening of bacterial symbionts of seagrass Enhalus sp. against biofilm-forming bacteria. Journal of Coastal Development, 13(2), 126-132.

Mossi, A. J., Mazutti, M., Paroul, N., Corazza, M. L., Dariva, C., Cansian, R. L., \& Oliveira, J. V. (2009). Chemical variation of tannins and triterpenes in Brazilian populations of Maytenus ilicifolia Mart. Ex Reiss. Brazilian Journal of Biology, 69(2), 339-345.

Nurjanah, N., Azka, A., \& Abdullah, A. (2012). Aktivitas antioksidan dan komponen bioaktif kangkung air (Ipomoea aquatica Forsk.). Jurnal Inovasi dan Kewirausahaan, 3(1), 152-158.

Nurjanah, N., Jacoeb, A. M., Hidayat, T., \& Shylina, A. (2015). Bioactive compounds and antioxidant activity of lindur stem bark (Bruguiera gymnorrhiza). International Journal of Plant Science and Ecology, 1(5), 182-189.

Raharjo, T. J. (2013). Kimia Hasil Alam. Yogyakarta, Indonesia: Pustaka Pelajar.

Ravikumar, S., Thajuddin, N., Suganthi, P., Inbaneson, S. J., \& Vinodkumar, T. (2010). Bioactive potential of seagrass bacteria against human bacterial pathogens. Journal of Environmental Biology, 31(3), 387-389.

Rohmatussolihat, R. (2015). Antioksidan, Penyelamat Sel-Sel Tubuh Manusia. Biotrends, 4(1), 5-9.

Santoso, J., Febrianti, F., \& Nurjanah, N. (2011). Kandungan fenol, komposisi kimia dan aktivitas antioksidan buah pedada (Sonneratia caseolaris). Jurnal Ilmu dan Teknologi Pangan, 9(1), 1-10.

Subhashini, P., Dilipan, E., Thangaradjou, T., \& Papenbrock, J. (2013). Bioactive natural products from marine angiosperms: abundance and functions. Natural products and bioprospecting, 3(4), 129-136.

Sudirman, S., Nurjanah, N., \& Jacoeb, A. M. (2016). Identifikasi struktur senyawa antioksidan buah lindur. Jurnal Pengolahan Hasil Perikanan Indonesia 19(2), 94-99.

Teffo, L. S., Aderogba, M. A., \& Eloff, J. N. (2010). Antibacterial and antioxidant activities of four kaempferol methyl ethers isolated from Dodonaea viscosa Jacq. var. angustifolia leaf extracts. South African Journal of Botany, 76(1), 25-29.

Tuwo, A. (2011). Pengelolaan Ekowisata Pesisir dan Laut. Surabaya, Indonesia: Brilian Internasional.

(C) 2017 by the authors; licensee Udayana University, Indonesia. This article is an open access article distributed under the terms and conditions of the Creative Commons Attribution license (http://creativecommons.org/licenses/by/3.0/). 